\title{
DETECTION AND FIRST MOLECULAR CHARACTERISATION OF THREE PICORNAVIRUSES FROM DIARRHOEIC CALVES IN TURKEY
}

\author{
Hakan IŞIDAN $^{1 *}$, Turhan TURAN ${ }^{1}$, Mustafa Ozan ATASOY $^{1}$, Ibrahim SÖZDUTMAZ $^{2}$ \\ and Bünyamin IREHAN ${ }^{3}$ \\ ${ }^{1}$ Department of Virology, Faculty of Veterinary Medicine, Cumhuriyet University, \\ 58140 Sivas, Turkey; ${ }^{2}$ Department of Virology, Faculty of Veterinary Medicine, \\ Erciyes University, Kayseri, Turkey; ${ }^{3}$ Veterinary Control Institute, Elazı̆̆ , Turkey
}

(Received 13 February 2018; accepted 2 May 2019)

The involvement of picornaviruses in calf diarrhoea was evaluated by the analysis of 127 faecal samples collected from diarrhoeic calves during 20142016. Virus detections were carried out by PCR using generic or specific primer pairs. One-third of the faecal samples $(33.86 \%)$ were found to be positive for one or more of the studied viruses. Bovine kobuvirus was detected in $22.83 \%$, bovine hungarovirus in $11.02 \%$, while bovine enterovirus 1 in $5.51 \%$ of the samples. The sequences of the PCR products indicated the existence of novel variants in all the three virus species. When comparing the partial sequences, the nucleotide sequence identities between our newly detected viruses and those previously deposited to the GenBank ranged between 76 and 99\%. Phylogenetic analyses revealed a novel lineage within the species Hunnivirus A. Our findings suggest that these viruses should be regarded as possible aetiological agents of calf diarrhoea. Based on the newly determined sequences, we designed and tested a new generic PCR primer set for the more reliable detection of bovine hungaroviruses. This is the first report on the molecular detection of the presence of bovine hungarovirus, bovine kobuvirus and bovine enterovirus 1 in the faecal samples of diarrhoeic calves in Turkey.

Key words: Bovine hungarovirus, bovine kobuvirus, bovine enterovirus 1, diarrhoea, calf, Turkey

Neonatal diarrhoea of calves is one of the most significant health problems in the cattle industry. Numerous aetiological agents including parasites (Cryptosporidium parvum, etc.), bacteria (Salmonella enterica, Escherichia coli, Clostridium perfringens, etc.) and viruses [bovine rotavirus (BRV), bovine coronavirus $(\mathrm{BCoV})$, bovine viral diarrhoea virus (BVDV), etc.] have been shown to be responsible for the diarrhoea of young calves (Bartels et al., 2010; Cho and Yoon, 2014). In addition, newly emerging viruses, including bovine torovirus (BToV),

*Corresponding author; E-mail: hisidan@cumhuriyet.edu.tr; Phone: 0090 (541) 610-2995; Fax: 0090 (346) 219-1812 
bovine norovirus and nebovirus, as well as bovine picornaviruses from the species Enterovirus E, Aichivirus B and Hunnivirus $A$ have also been reported as enteric disease agents in calves (Pham et al., 2007; Reuter et al., 2011; Cho and Yoon, 2014).

Together with Dicistroviridae, Iflaviridae, Marnaviridae, Secoviridae and some unassigned viruses, the family Picornaviridae is a member of the order Picornavirales (MacLachlan and Dubovi, 2017). Members of the family Picornaviridae share basic characteristics such as the shape and the small size (approximately $30 \mathrm{~nm}$ in diameter) of the non-enveloped virion, as well as the single-stranded, positive sense RNA genome of approximately 7.5 to $8.5 \mathrm{~kb}$ in size (Zell, 2018). Picornaviridae is a large virus family currently containing more than 35 distinct genera according to the International Committee on Taxonomy of Viruses, ICTV (http://www.ictvonline.org). Three classified genera of the family are Hunnivirus, Kobuvirus and Enterovirus, members of which have been reported to cause gastrointestinal infections in cattle (Zell et al., 2017).

The genus Enterovirus contains about 15 species (Enterovirus $A$ to $L$ and Rhinovirus $A$ to $C$ ) at present (Zell et al., 2017). These occur in humans and different animal species including cattle and swine. The species Enterovirus $E$ and $F$ which contain bovine enterovirus 1 and 2 (BEV-1 and 2), respectively, are regarded as aetiological agents in bovine gastrointestinal, respiratory and reproductive diseases (Knowles and Mann, 1990; Blas-Machado et al., 2007).

The genus Kobuvirus, being also a member of the family Picornaviridae, currently includes six species named as Aichivirus $A$ to $E$, out of which Aichivirus $B$ contains bovine kobuvirus (BKV) (Zell et al., 2017). Kobuviruses/ Aichiviruses were first detected in human diarrhoeic stool specimens obtained from an oyster-associated gastroenteritis outbreak in Japan (Yamashita et al., 1991). Since then, kobuviruses have been detected worldwide in humans as well as in many domestic animal species including cattle, sheep, ferret and goat (Yamashita et al., 2003; Di Martino et al., 2012; Smits et al., 2013; Melegari et al., 2016; Otomaru et al., 2016; Pankovics et al., 2016). Since BKV has been detected in connection with calf diarrhoea, it can be considered an emerging bovine virus (Khamrin et al., 2008; Park et al., 2011). More recent studies have revealed that aichiviruses may also occur in different laboratory-bred or free-living rats (Rattus norvegicus, $R$. tanezumi, $R$. argentiventer and Bandicota indica) in the USA (Firth et al., 2014) as well as in China (Du et al., 2016).

Hunnivirus $A$ containing bovine hungarovirus $(\mathrm{BHuV})$ is the only species in the genus Hunnivirus. It was first detected from sheep and cattle in Hungary in 2008 and 2009 and had been named initially as bovine and ovine hungarovirus 1, respectively (Reuter et al., 2012).

Evidence for the presence of BEV-1 in Turkey has already been reported based on serological surveys without direct virus detection (Yilmaz et al., 2011). Our aim was to screen faecal samples of diarrhoeic calves for selected picorna- 
viruses. Partial sequence characterisation of any newly detected viruses was also planned.

\section{Materials and methods}

\section{Samples and RNA isolation}

A total of 127 faecal samples (rectal swabs) from diarrhoeic calves, up to one month old, on 76 small farms (with less than 20 animals) were collected during 2014-2016 from three provinces (Sivas, Malatya and Elazığ) located in the central Turkish inland. The collected faecal samples were transported to the laboratory as soon as possible, then stored in an ultra-deep freezer at $-80{ }^{\circ} \mathrm{C}$ until the RNA isolation step. The samples had been tested for the presence of common viral enteric pathogens (BRV, BCoV, BVDV and $\mathrm{BToV}$ ) previously.

To remove large cellular debris, faecal samples were diluted in $1 \mathrm{M}$ phosphate buffered saline solution (1/10) and centrifuged at $5000 \mathrm{rpm}$ for $5 \mathrm{~min}$. The supernatants were submitted to the nucleic acid extraction procedure by using the Vivantis GF-1 Viral Nucleic Acid Extraction Kit according to the manufacturer's instructions (Vivantis Technologies, Malaysia). Eluted nucleic acids were stored in $-80^{\circ} \mathrm{C}$ until use.

\section{Genomic data analysis and primer design}

Because of the genetic diversity of picornaviruses, we designed new PCR primers in order to broaden the detection limits for $\mathrm{BEVs}, \mathrm{BKV}$ and $\mathrm{BHuV}$. Nucleotide sequences of these viral agents (94 for BEV-1 and 2 entries, $20 \mathrm{BHuV}$ entries and 158 individual BKV sequences) were downloaded from the GenBank, and multiple alignments were prepared by using Cluster $\mathrm{W}$ plugin of Unipro UGENE software version 1.21. (Okonechnikov et al., 2012). A generic detection primer pair which covers all the sequences deposited in GenBank, for BEV-1 5' UTR region was designed using primer3 plugin of BENCHLING online molecular analysis software (http://www.benchling.com). A new detection primer pair amplifying the highly conserved 5' UTR region of the BHuV genome was also designed using the same software. For the detection of BKV, we used the primer pair 'UNIV-kobu-F/R' designed and published previously (Reuter and Egyed, 2009). All primers used in this study are listed in Table 1.

\section{Reverse transcription polymerase chain reaction ( $R T-P C R)$}

The cDNA synthesis was carried out in a $25 \mu 1$ final volume containing $4 \mu \mathrm{l}$ of RNA extract, $10 \mathrm{mM}$ deoxy-nucleoside triphosphate (dNTP), $2.5 \mu \mathrm{l} 10 \times$ RT buffer $\left(50 \mathrm{mM}\right.$ Tris- $\mathrm{HCl}, \mathrm{pH} 8.3$ at $25^{\circ} \mathrm{C}, 75 \mathrm{mM} \mathrm{KCl}, 3 \mathrm{mM} \mathrm{MgCl} 2$ and $10 \mathrm{mM}$ DTT), $50 \mathrm{ng}$ of random hexamer, $40 \mathrm{U}$ RNasin, $200 \mathrm{U}$ M-MuLV Reverse-Transcriptase (Vivantis, Germany). The reverse transcription was per- 
formed at $37^{\circ} \mathrm{C}$ for $1 \mathrm{~h}$. The PCR was conducted in a $50 \mu \mathrm{l}$ final volume using $5 \mu \mathrm{l}$ of the RT reaction mixture as template, along with $5 \mu 110 \times$ PCR buffer, $10 \mathrm{mM}$ dNTP, $10 \mathrm{pmol} / \mu 1$ of each sense/antisense primer, and $5 \mathrm{U}$ of Taq DNA Polymerase (Vivantis, Germany). The following PCR program was used: an initial step at $95^{\circ} \mathrm{C}$ for 2 min followed by 40 cycles of denaturation at $94{ }^{\circ} \mathrm{C}$ for $40 \mathrm{~s}$, primer annealing $\left(49^{\circ} \mathrm{C}\right.$ for $\mathrm{BKV}, 57^{\circ} \mathrm{C}$ for $\mathrm{BHuV}$ and $59^{\circ} \mathrm{C}$ for $\mathrm{BEV}$ ) for $30 \mathrm{~s}$, and elongation at $72{ }^{\circ} \mathrm{C}$ for $1 \mathrm{~min}$. The final elongation step was at $72{ }^{\circ} \mathrm{C}$ for $10 \mathrm{~min}$.

Table 1

PCR primers used in this study

\begin{tabular}{|c|c|c|c|c|}
\hline Primer name & Target & Sequences $\left(5^{\prime}-3^{\prime}\right)$ & $\begin{array}{l}\text { Amplicon } \\
\text { length }\end{array}$ & References \\
\hline $\begin{array}{l}\text { Entero1-F } \\
\text { Entero1-R }\end{array}$ & $\begin{array}{l}\text { 5' UTR region } \\
\text { of bovine } \\
\text { enterovirus }\end{array}$ & $\begin{array}{l}\text { GTACCTTTGTACGCCTGTT } \\
\text { AGGATTAGCCGCATTCA }\end{array}$ & 488 bp & $\begin{array}{c}\text { Knowles and } \\
\text { Mann, } 1990\end{array}$ \\
\hline $\begin{array}{l}\text { Entero274-F } \\
\text { Entero564-R }\end{array}$ & $\begin{array}{l}\text { 5' UTR region } \\
\text { of bovine } \\
\text { enterovirus }\end{array}$ & $\begin{array}{l}\text { TCAAGCACTYCTGTYTCCCCGG } \\
\text { CTCGGAGGTTRGGATTAGCAGC }\end{array}$ & $291 b p$ & This study \\
\hline $\begin{array}{l}\text { UNIV-kobu-F } \\
\text { UNIV-kobu-R }\end{array}$ & $\begin{array}{c}\text { 3D Region of } \\
\text { bovine } \\
\text { kobuvirus }\end{array}$ & $\begin{array}{l}\text { TGGAYTACAAGTGTTTTGATGC } \\
\text { ATGTTGTTRATGATGGTGTTGA }\end{array}$ & $216 b p$ & $\begin{array}{l}\text { Reuter and } \\
\text { Egyed, } 2009\end{array}$ \\
\hline $\begin{array}{l}\text { Hungaro-3D-F } \\
\text { Hungaro-3D-R }\end{array}$ & $\begin{array}{l}\text { 3D Region } \\
\text { of bovine } \\
\text { hungarovirus }\end{array}$ & $\begin{array}{l}\text { GAYTATTCKGGATTTGATGC } \\
\text { CATYACYGGGCGAACAAG }\end{array}$ & $465 b p$ & $\begin{array}{c}\text { Reuter et al., } \\
2012\end{array}$ \\
\hline $\begin{array}{l}\text { Hunni166-F } \\
\text { Hunni477-R }\end{array}$ & $\begin{array}{l}\text { 5' UTR region } \\
\text { of bovine } \\
\text { hungarovirus }\end{array}$ & $\begin{array}{l}\text { TCAGTCGAAGCCGCTTGGAATA } \\
\text { GTGCTGTWAACACCGTGGCTTT }\end{array}$ & $312 b p$ & This study \\
\hline
\end{tabular}

\section{Sequencing and phylogenetic analysis}

The PCR amplicons were purified with a Wizard SV Gel and PCR CleanUp System (Promega, Madison, WI) and sequenced using the BigDye Terminator Cycle Sequencing Kit (Applied Biosystems, Foster City, CA) on an automated sequencer (ABI 3100; Applied Biosystems, Foster City, CA). All of the sequence outputs were aligned with use of MUSCLE algorithm.

Phylogenetic trees were reconstructed in Unipro UGENE package version 1.21. (Okonechnikov et al., 2012) using neighbour-joining tree building method and Tamura-Nei's genetic distance model with 1,000 bootstrap replicates. The sequences used in the phylogenetic analyses are listed in Tables 2, 3 and 4. 
Table 2

Description of bovine kobuviruses used in the phylogenetic analysis (Fig. 2)

\begin{tabular}{|c|c|c|c|c|c|}
\hline No. & Designation & Country & Year & Host & Accession number \\
\hline 1 & D40 & China & 2010 & Bovine & KF728677.1 \\
\hline 2 & GN1155 & China & 2010 & Bovine & KF728693.1 \\
\hline 3 & B1213 & China & 2007 & Bovine & KF728676.1 \\
\hline 4 & SZ7 & China & 2008 & Bovine & KF728698.1 \\
\hline 5 & T0158 & China & 2010 & Bovine & KF728700.1 \\
\hline 6 & $\mathrm{X} 1-07078$ & China & 2007 & Bovine & KF728703.1 \\
\hline 7 & $\mathrm{X} 3-23$ & China & 2007 & Bovine & KF728708.1 \\
\hline 8 & H18 & China & 2010 & Bovine & KF728689.1 \\
\hline 9 & CMB02 & Thailand & - & - & EF659450.1 \\
\hline 10 & U-1 & Japan & - & - & NC_004421.1 \\
\hline 11 & $\mathrm{~N}-2$ & Japan & - & Bovine & $\mathrm{AB} 097157.1$ \\
\hline 12 & $\mathrm{~K}-38$ & Japan & - & Bovine & AB097157.1 \\
\hline 13 & $\mathrm{~K}-49$ & Japan & - & Bovine & AB097159.1 \\
\hline 14 & $\mathrm{~K}-3$ & Japan & - & Bovine & AB097152.1 \\
\hline 15 & K-44 & Japan & - & Bovine & AB097158.1 \\
\hline 16 & K-60 & Japan & - & - & AB097161.1 \\
\hline 17 & K-55 & Japan & - & Bovine & AB097160.1 \\
\hline 18 & 08KB680 & South Korea & 2008 & Bovine & JQ026109.1 \\
\hline 19 & bovine/CPF3419/2008/Korea & South Korea & 2008 & Bovine & HQ234905.1 \\
\hline 20 & bovine/CPF3423/2008/Korea & South Korea & 2008 & Bovine & HQ234906.1 \\
\hline 21 & bovine/CPF7030/2009/Korea & South Korea & 2009 & Bovine & HQ234910.1 \\
\hline 22 & KB40 & South Korea & 2010 & Bovine & HQ650176.1 \\
\hline 23 & KB8 & South Korea & 2008 & Bovine & HQ650166.1 \\
\hline 24 & KB96 & South Korea & 2010 & Bovine & HQ650196.1 \\
\hline 25 & BoKoV-164-BRA-BU & Brazil & 2012 & Bovine & KP164581.1 \\
\hline 26 & 1830 & Northern Ireland & 2011 & Bovine & КC928134.1 \\
\hline 27 & 17497 & Northern Ireland & 2009 & Bovine & KC928132.1 \\
\hline 28 & 17511 & Northern Ireland & 2009 & Bovine & КC928130.1 \\
\hline 29 & 17518 & Northern Ireland & 2009 & Bovine & КC928133.1 \\
\hline 30 & 20021 & Northern Ireland & 2009 & Bovine & КС928131.1 \\
\hline 31 & 104TE-11 ITA & Italy & 2011 & Bovine & JX070084.1 \\
\hline 32 & $106 \mathrm{R} / \mathrm{IT}$ & Italy & 2014 & Roe deer & KP864078.1 \\
\hline 33 & 109TE-11-ITA & Italy & 2011 & Bovine & JQ900632.1 \\
\hline 34 & 118TE-11-ITA & Italy & 2011 & Bovine & JQ900633.1 \\
\hline 35 & 21TE-11-ITA & Italy & 2011 & Bovine & JQ900630.1 \\
\hline 36 & 81TE-11-ITA & Italy & 2011 & Bovine & JQ900631.1 \\
\hline 37 & 8TE-11-ITA & Italy & 2011 & Bovine & JQ900629.1 \\
\hline 38 & $95 \mathrm{R} / \mathrm{IT}$ & Italy & 2014 & Roe deer & KP864077.1 \\
\hline 39 & HC818 & UK & 2013 & Bovine & KR911601.1 \\
\hline 40 & HC832 & UK & 2013 & Bovine & KR911608.1 \\
\hline 41 & $\mathrm{SC} 1$ & UK & 2013 & Bovine & KT003671.1 \\
\hline 42 & SC 840 & UK & 2013 & Bovine & KR911609.1 \\
\hline 43 & SC848 & UK & 2013 & Bovine & KR911611.1 \\
\hline 44 & SC863 & UK & 2013 & Bovine & KR911617.1 \\
\hline 45 & AIV-BOLAT2-16-TUR & Turkey & 2016 & Bovine & KY695136.1 \\
\hline 46 & AIV-BOLAT8-16-TUR & Turkey & 2016 & Bovine & KY695137.1 \\
\hline 47 & AIV-BOLAT13-16-TUR & Turkey & 2016 & Bovine & KY695138.1 \\
\hline 48 & AIV-BOLAT14-16-TUR & Turkey & 2016 & Bovine & KY695139.1 \\
\hline 49 & AIV-BOLAT16-16-TUR & Turkey & 2016 & Bovine & KY695140.1 \\
\hline 50 & AIV-BOLAT33-16-TUR & Turkey & 2016 & Bovine & KY695141.1 \\
\hline 51 & AIV-BOLAT55-16-TUR & Turkey & 2016 & Bovine & KY695142.1 \\
\hline 52 & AIV-BOLAT69-16-TUR & Turkey & 2016 & Bovine & KY695143.1 \\
\hline 53 & AIV-BOLAT110-16-TUR & Turkey & 2016 & Bovine & KY695144.1 \\
\hline 54 & AIV-BOLAT112-16-TUR & Turkey & 2016 & Bovine & KY695145.1 \\
\hline 55 & AIV-BOLAT113-16-TUR & Turkey & 2016 & Bovine & KY695146.1 \\
\hline 56 & AIV-BOLAT114-16-TUR & Turkey & 2016 & Bovine & KY695147.1 \\
\hline 57 & AIV-BOLAT117-16-TUR & Turkey & 2016 & Bovine & KY695148.1 \\
\hline 58 & AIV-BOLAT125-16-TUR & Turkey & 2016 & Bovine & KY695149.1 \\
\hline
\end{tabular}


Table 3

Description of hunniviruses used in the phylogenetic analysis (Fig. 3)

\begin{tabular}{|c|c|c|c|c|c|}
\hline No. & Designation & Country & Year & Host & Accession number \\
\hline 1 & 83GR-70-RAT106 & Vietnam & 2012 & Rattus argentiventer & KT944212.1 \\
\hline 2 & 83GR-70-RAT130 & Vietnam & 2012 & Rattus argentiventer & KT944213.1 \\
\hline 3 & 05VZ-75-RAT099 & Vietnam & 2013 & Rattus tanezumi & KT944214.1 \\
\hline 4 & NrHuV/NYC-E21 & USA & 2012 & Rattus norvegicus & NC_025675.1 \\
\hline 5 & BHUV1/2008/HUN & Hungary & 2008 & Bovine & $\mathrm{NC}^{-} 018668.1$ \\
\hline 6 & OHUV1/2009/HUN & Hungary & 2009 & Ovine & НМ153767.3 \\
\hline 7 & HUV-BOLAT37-16-TUR & Turkey & 2016 & Bovine & KY974326.1 \\
\hline 8 & HUV-BOLAT55-16-TUR & Turkey & 2016 & Bovine & KY974327.1 \\
\hline 9 & HUV-BOLAT95-16-TUR & Turkey & 2016 & Bovine & KY974328.1 \\
\hline 10 & HUV-BOLAT89-16-TUR & Turkey & 2016 & Bovine & KY974329.1 \\
\hline 11 & HUV-BOLAT83-16-TUR & Turkey & 2016 & Bovine & KY974330.1 \\
\hline 12 & HUV-BOLAT75-16-TUR & Turkey & 2016 & Bovine & KY974331.1 \\
\hline 13 & HUV-BOLAT58-16-TUR & Turkey & 2016 & Bovine & KY974332.1 \\
\hline 14 & HUV-BOLAT1-16-TUR & Turkey & 2016 & Bovine & KY974333.1 \\
\hline
\end{tabular}

\section{Results and Discussion}

The PCR screening allowed the detection of some representatives of all the three picornavirus species in the faecal samples of diarrhoeic calves tested in this study. The most prevalent was BKV, present in 29 samples $(22.83 \%)$. We found seven samples $(5.51 \%)$ positive for the RNA of BEV-1 by both primer sets. Interestingly, for $\mathrm{BHuV}, 6(4.72 \%)$ and 14 samples $(11.02 \%)$ were found positive by the use of the Hungaro-3D-F/R or the Hunni166-F/477-R primer sets, respectively. The overall detection results are summarised in Fig. 1.

The aim of this study was to clarify the potential role of picornaviruses (namely members of the species Enterovirus E, Hunnivirus A, and Aichivirus B) in clinical disease. More than one-third (33.86\%) of the 127 samples collected from calves with diarrhoea was found to contain one or more of the three agents.

We designed two generic primer sets for the detection of BEVs and $\mathrm{BHuV}$, based on alignments of the large sequence data available in the GenBank at present. For the detection of BEV-1, both primer pairs gave identical results in our study. However, for the detection of $\mathrm{BHuV}$, the newly designed primers (Hunni166-F/477-R) that target the 5' UTR region, gave more positive results than the Hungaro-3D-F/R primer set (Reuter and Egyed, 2009). Nonetheless, for phylogenetic studies, this primer set that targets the $3 \mathrm{D}$ region of the virus is perhaps a better choice than the novel primer set. For screening faecal samples for the presence of $\mathrm{BHuV}$, the use of our more robust primer set can be recommended. 
Table 4

Description of bovine enteroviruses used in the phylogenetic analysis (Fig. 4)

\begin{tabular}{|c|c|c|c|c|c|}
\hline No. & Designation & Country & Year & Host & Accession number \\
\hline 1 & BEV/Thailand/E5 & Thailand & 2013 & Bovine & KT992109.1 \\
\hline 2 & BEV/Thailand/D5 & Thailand & 2013 & Bovine & KT992103.1 \\
\hline 3 & BEV/Thailand/E18 & Thailand & 2013 & Bovine & KT992111.1 \\
\hline 4 & BEV/Thailand/F11 & Thailand & 2013 & Bovine & KT992114.1 \\
\hline 5 & BEV/Thailand/F17 & Thailand & 2013 & Bovine & KT992116.1 \\
\hline 6 & $\mathrm{BEV} /$ Thailand/F22 & Thailand & 2013 & Bovine & KT992117.1 \\
\hline 7 & HY 12 & China & 2012 & Bovine & KF748290.1 \\
\hline 8 & BEV IS1/Bos taurus/JPN/1990 & Japan & 1990 & Bovine & LC150009.1 \\
\hline 9 & BEV IS2/Bos taurus/JPN/1991 & Japan & 1991 & Bovine & LC150010.1 \\
\hline 10 & BEV Ho12/Bos taurus/JPN/2014 & Japan & 2014 & Bovine & LC150008.1 \\
\hline 11 & VG-5-27 & - & - & - & $\mathrm{NC} 001859.1$ \\
\hline 12 & Vir 404/03 & - & - & - & DQ0992771.1 \\
\hline 13 & D $8 / 01$ & Germany & - & - & DQ092782.1 \\
\hline 14 & E 6-82 & Germany & - & - & DQ092776.1 \\
\hline 15 & SD 1182 II & Germany & - & - & DQ092784.1 \\
\hline 16 & D $14 / 3 / 96$ & Germany & - & - & DQ092786.1 \\
\hline 17 & D 58/96-V2130 & Germany & - & - & DQ092772.1 \\
\hline 18 & VD 2860/1-99 & Germany & - & - & DQ092774.1 \\
\hline 19 & $56 / 59 / 1$ & Germany & - & - & DQ092778.1 \\
\hline 20 & Jena 38/02 & Germany & - & - & DQ092788.1 \\
\hline 21 & D $3 / 98$ & Germany & - & - & DQ092790.1 \\
\hline 22 & D $14 / 1 / 96$ & Germany & - & - & DQ092780.1 \\
\hline 23 & RM-2 & - & - & - & X79369.2 \\
\hline 24 & PA12-24791 & USA & 2012 & Bovine & KC667561.1 \\
\hline 25 & LC-R4 & USA & - & Bovine & DQ092769.1 \\
\hline 26 & PS 42 & USA & - & Bovine & DQ092792.1 \\
\hline 27 & PS 83 & USA & - & Bovine & DQ092793.1 \\
\hline 28 & IL/alpaca & USA & 2007 & Alpaca & KC748420.1 \\
\hline 29 & MexKSU/5 & Mexico & 2015 & Bovine & KU172420.1 \\
\hline 30 & BEV/Egypt/1 & Egypt & 2014 & Bovine & KM887136.1 \\
\hline 31 & $\mathrm{BEV} / \mathrm{Egypt} / 2$ & Egypt & 2014 & Bovine & KM887137.1 \\
\hline 32 & BEV/Egypt/3 & Egypt & 2014 & Bovine & KM887138.1 \\
\hline 33 & $\mathrm{BEV} / \mathrm{Egypt} / 4$ & Egypt & 2014 & Bovine & KM887139.1 \\
\hline 34 & $\mathrm{BEV} / \mathrm{Egypt} / 5$ & Egypt & 2014 & Bovine & KM887140.1 \\
\hline 35 & BEV/Egypt/6 & Egypt & 2014 & Bovine & KM887141.1 \\
\hline 36 & BEV-Bolat12-16-TUR & Turkey & 2016 & Bovine & MF667937.1 \\
\hline 37 & BEV-Bolat20-16-TUR & Turkey & 2016 & Bovine & MF667938.1 \\
\hline 38 & BEV-Bolat42-16-TUR & Turkey & 2016 & Bovine & MF667939.1 \\
\hline 39 & BEV-Bolat63-16-TUR & Turkey & 2016 & Bovine & MF667940.1 \\
\hline 40 & BEV-Bolat64-16-TUR & Turkey & 2016 & Bovine & MF667941.1 \\
\hline 41 & BEV-Bolat86-16-TUR & Turkey & 2016 & Bovine & MF667942.1 \\
\hline
\end{tabular}

In several previous reports, it has been demonstrated that BKV can be detected from clinically healthy animals as frequently as from diarrhoeic ones (Reuter and Egyed, 2009; Jeoung et al., 2011). Some other studies have reported a higher rate of positivity in diarrhoeic calves (Barry et al., 2011; Jeoung et al., 2011; Park et al., 2011; Candido et al., 2017). BKV has been detected in 5\% $(2 / 40)$ of adult cattle, and in $20.9 \%$ (38/182) of diarrhoeic calf samples in Brazil 
(Blas-Machado et al., 2011; Ribeiro et al., 2014). It has also been detected in $16.7 \%(12 / 72)$ and $6.2 \%$ of healthy cattle in Japan and in Hungary, respectively (Khamrin et al., 2008; Reuter and Egyed, 2009), as well as in 25.8\% (16/62) of diarrhoeic cattle in South Korea (Park et al., 2011). On the other hand, the highest proportion of samples from diarrhoeic cattle has been found to be positive for BKV, namely 34.6\% (37/107) and 77.8\% (7/9) in South Korea (Park et al., 2011) and in the Netherlands (Barry et al., 2011), respectively. In our study also, BKV was detected in the highest proportion of faecal samples collected from young diarrhoeic calves up to 1 month of age.

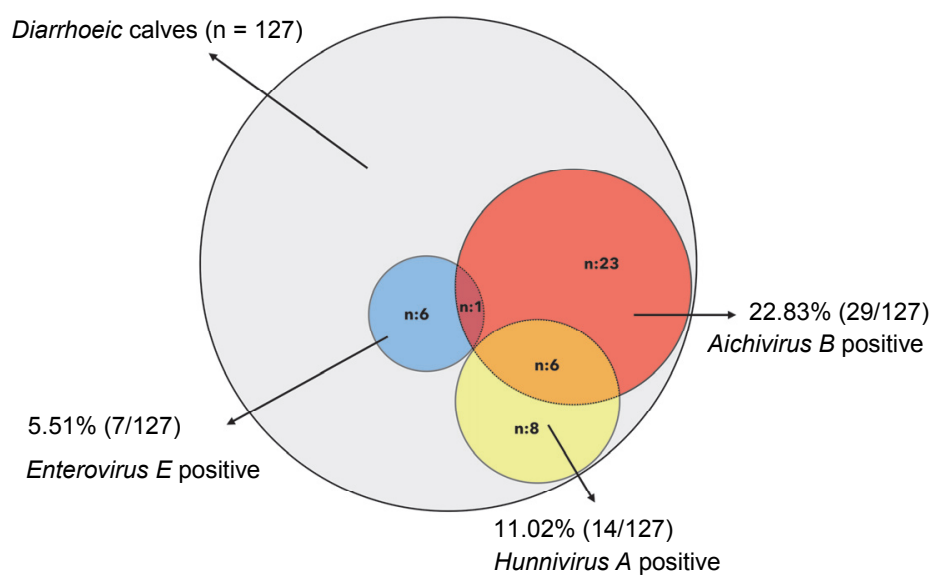

Fig. 1. Overall detection results of three picornaviral agents (Bovine enterovirus E, Aichivirus $B$ and Hunnivirus $A$ ) by RT-PCR analysis

Enteric, respiratory and reproductive diseases have been described in association with BEV infections in cattle (Jiménez-Clavero et al., 2005). As the main route of transmission is the faecal-oral route, BEV has been proposed as an indicator of faecal pollution originating from animals (Ley et al., 2002; Li et al., 2012). According to a study conducted in Spain in 2004, 78.0\% (78 of 100) of the tested faecal samples were BEV positive (Ley et al., 2002). In China, 24.6\% of faecal samples (17/69) from diarrhoeic and healthy cattle have been found positive for the presence of BEV RNA (Li et al., 2012). Although there is no report on direct virus detection, different epizootiological studies have indicated the presence of BEV-specific antibodies in $41.8-67.7 \%$ of goats, in $3.9 \%$ of water buffalos and $64.8 \%$ of cattle, detected by virus neutralisation assay in Turkey (Acar and Gur, 2009; Gür et al., 2006; Gür et al., 2008). In this study, we detected the presence of BEV-1 RNA for the first time in Turkey.

We submitted 14 novel partial BKV sequences to the GenBank (accession numbers: KY695136-KY695149). According to the results of blast, our newly acquired sequences of the 217-nt-long fragment shared $89.4-99.0 \%$ identity 
among each other, and 74.8-97.1\% nucleotide identity with those previously deposited in the GenBank. Phylogenetic analysis was applied to the data and these clustered on distinct branches among the 182 other sequences retrieved from the GenBank. We furthermore limited the phylogenetic tree to 58 strains to simplify (Fig. 2), which revealed that some of them appeared close to the Brazilian sequences, while others were closer to those found in Japan or South Korea. This result indicates that a moderate level of genetic diversity exists among Turkish strains.

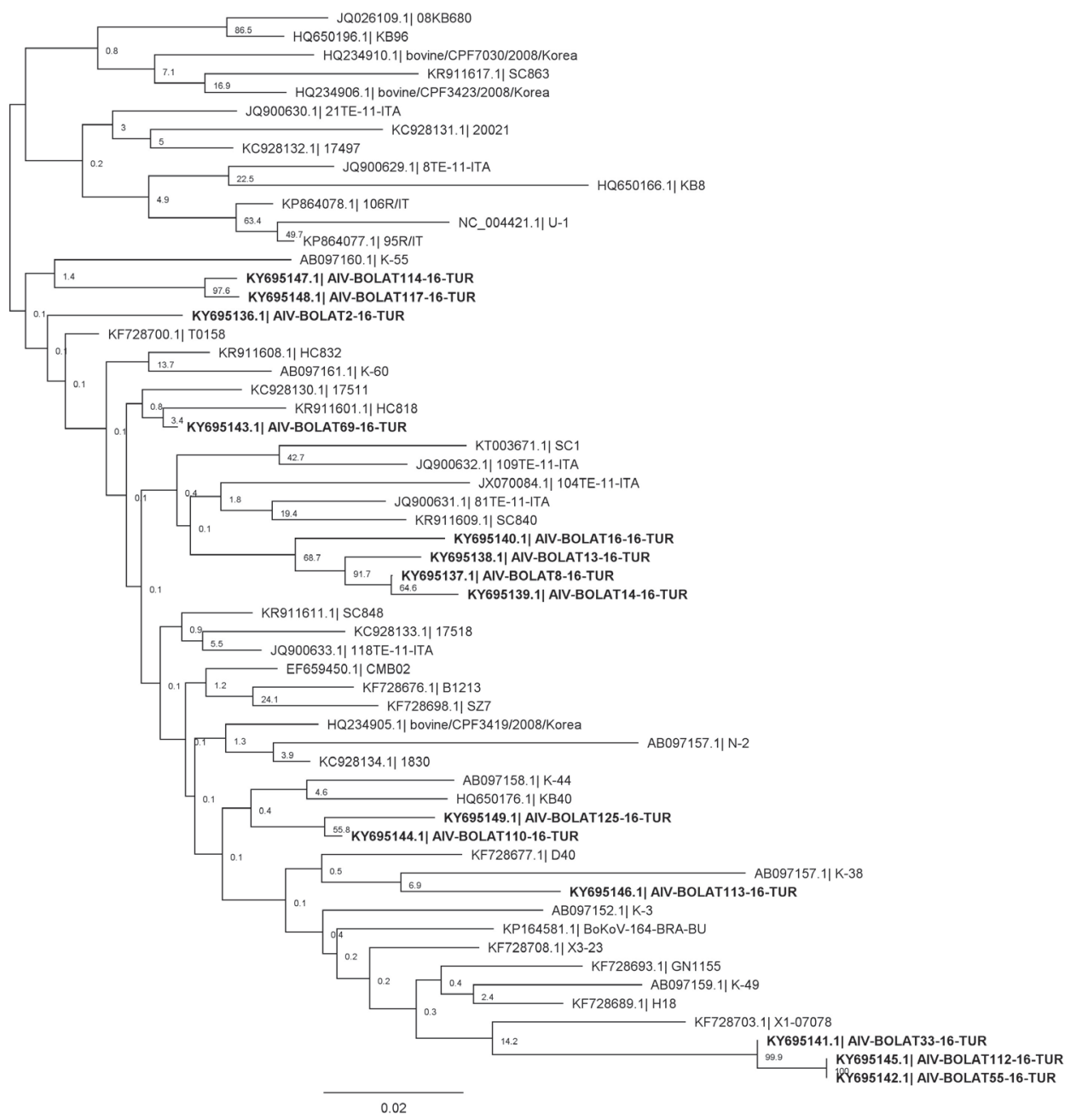

Fig. 2. Phylogenetic analysis based on the 217-bp partial nucleotide sequence of the 3D region of bovine kobuviruses (NJ tree, Tamura-Nei genetic distance model). The bootstrap values were generated with 1,000 pseudoreplicates. The name and description of viruses are listed in Table 2. Novel virus sequences, acquired in the present study, are highlighted in bold 
Bovine hungarovirus (species Hunnivirus $A$ ) is a recently discovered virus (Reuter et al., 2012). According to the phylogenetic analysis, the eight Turkish BHuV sequences (GenBank accession numbers: KY974326-KY974333) clustered with the Hungarian bovine hungaroviruses and some them formed a separate, novel lineage (Fig. 3). Considering the 301-bp PCR fragment, the nucleotide identity among the Turkish hunnivirus sequences ranged between 76.02 and $99.02 \%$. The identity ranged between 75.4 and $91.8 \%$ when comparing them to the Hungarian bovine hunnivirus sequence. The nucleotide identity was 75.1$82.3 \%$ between the Turkish $\mathrm{BHuV}$ and the Hungarian ovine sequence. The partial rat hunnivirus sequences shared 66.4 to $77.9 \%$ identity with the Turkish BHuV sequences.

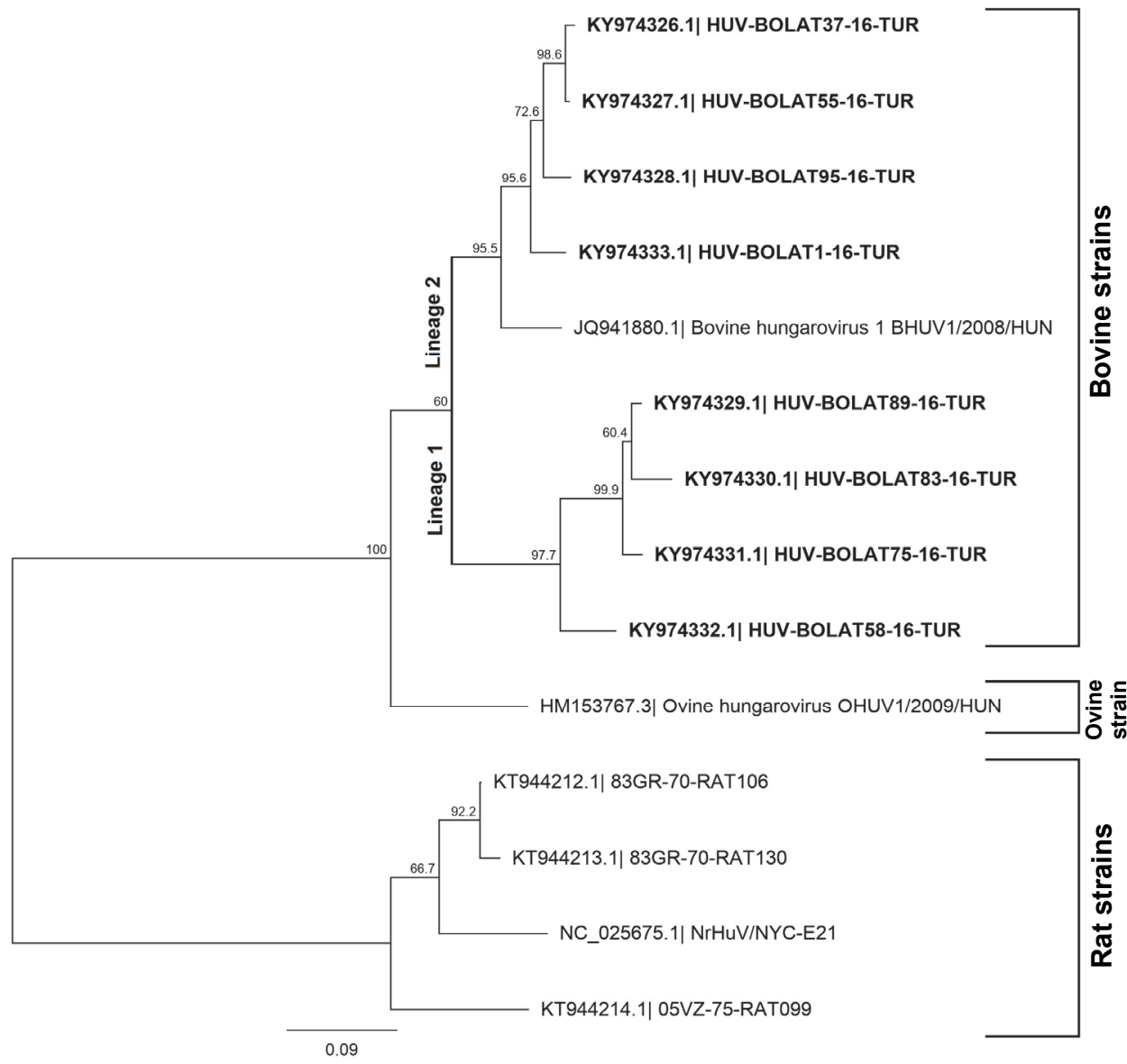

Fig. 3. Phylogenetic analysis based on the 306-bp partial nucleotide sequence of the 5' UTR region of hunniviruses (NJ tree, Tamura-Nei genetic distance model). The bootstrap values were generated with 1,000 pseudoreplicates. The name and description of viruses are listed in Table 3. Novel virus sequences, acquired in the present study, are highlighted in bold 
On the other hand, the six novel BEV-1 sequences (GenBank accession numbers: MF667937-MF667942) occupied the same branch of the phylogenetic tree (Fig. 4). The nucleotide identity of the 293-bp partial sequence of the 5' UTR region was found to be $90.14-92.81 \%$ among the novel Turkish sequences, and ranged between 72.28 to $92.18 \%$ between the Turkish and other, previously sequenced fragments.

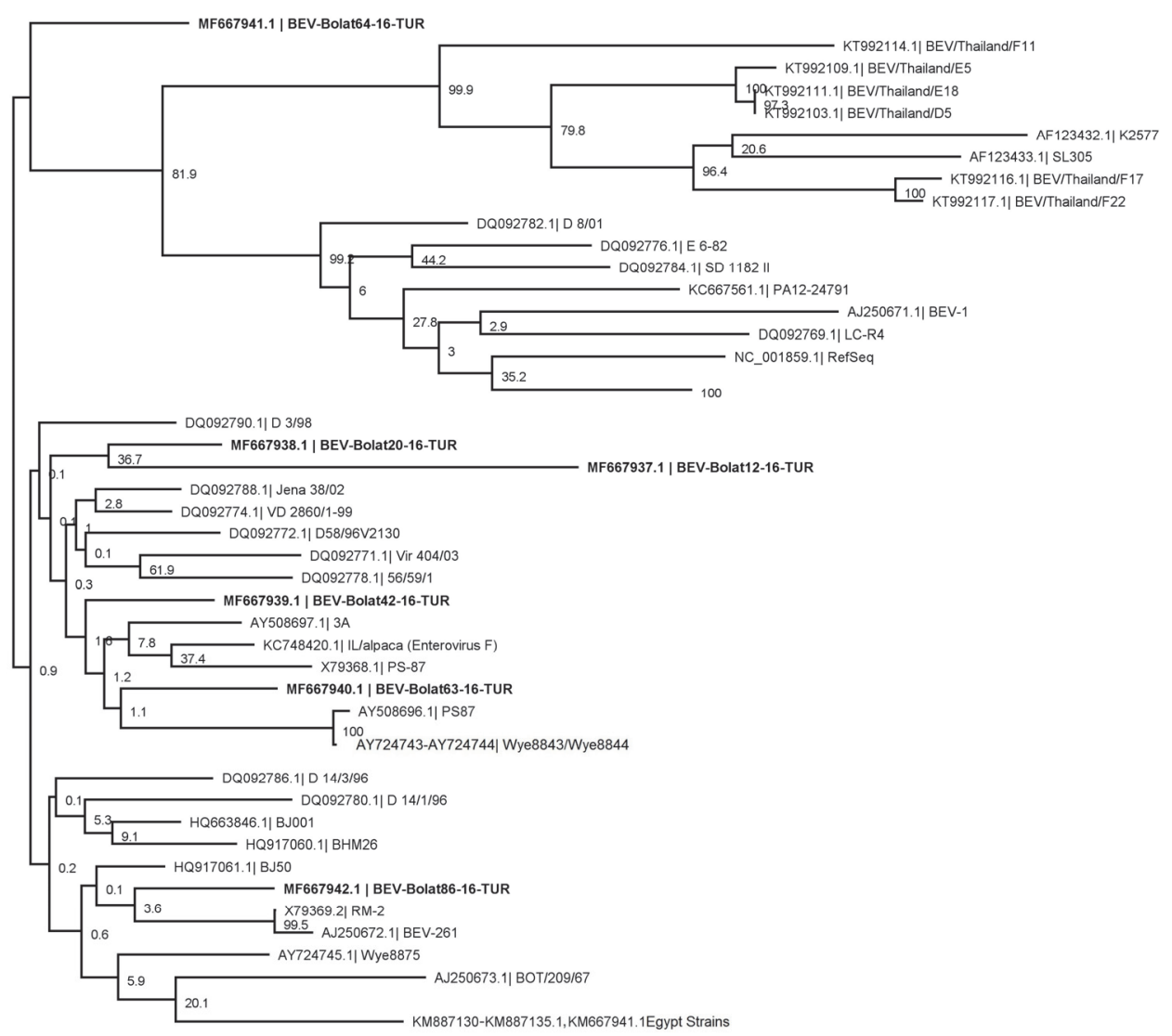

0.03

Fig. 4. Phylogenetic analysis based on the 293-bp partial nucleotide sequence of the 5' UTR region of bovine enteroviruses (NJ tree, Tamura-Nei genetic distance model). The bootstrap values were generated with 1,000 pseudoreplicates. The name and description of viruses are listed in Table 4.

Novel virus sequences, acquired in the present study, are highlighted in bold

In conclusion, this study indicates that these viral agents can be detected in diarrhoeic calves in Turkey. Based on the PCR results we suggest that the Hun- 
ni166-F/477-R primer set should be used instead of Hungaro3D-F/R for the detection of $\mathrm{BHuV}$. The impact of $\mathrm{BEV}$ and $\mathrm{BHuV}$ in the problem of calf diarrhoea remains questionable unless experimental studies can confirm it. Nonetheless, our results provide a strong evidence for the role of BKV as an enteric pathogen that can cause diarrhoea in calves. We report here a more reliable detection tool for $\mathrm{BHuV}$ and also a novel lineage of $\mathrm{BHuV}$. Furthermore, this is the first report on the molecular detection of these three picornaviruses in Turkey.

\section{Acknowledgement}

This research was supported by the Cumhuriyet University Scientific Research Project Foundation (CÜBAP) project no: VET-029.

\section{References}

Acar, A. and Gur, S. (2009): Seroprevalence of bovine enterovirus type 1 (BEV1) in goats in Turkey. J. Anim. Vet. Adv. 8, 1075-1078.

Barry, A. F., Ribeiro, J., Alfieri, A. F., van der Poel, W. H. and Alfieri, A. A. (2011): First detection of kobuvirus in farm animals in Brazil and the Netherlands. Infect. Genet. Evol. 11, $1811-1814$.

Bartels, C. J. M., Holzhauer, M., Jorritsma, R., Swart, W. A. and Lam, T. J. (2010): Prevalence, prediction and risk factors of enteropathogens in normal and non-normal faeces of young Dutch dairy calves. Prev. Vet. Med. 93, 162-169.

Blas-Machado, U., Saliki, J. T., Boileau, M. J., Goens, S. D., Caseltine, S. L., Duffy, J. C. and Welsh, R. D. (2007): Fatal ulcerative and hemorrhagic typhlocolitis in a pregnant heifer associated with natural bovine enterovirus type-1 infection. Vet. Pathol. 44, 110-115.

Blas-Machado, U., Saliki, J. T., Sánchez, S., Brown, C. C., Zhang, J., Keys, D., Woolums, A. and Harvey, S. B. (2011): Pathogenesis of a bovine enterovirus-1 isolate in experimentally infected calves. Vet. Pathol. 48, 1075-1084.

Candido, M., Batinga, M. C., Alencar, A. L., de Almeida-Queiroz, S. R., da Gloria Buzinaro, M., Livonesi, M. C., Fernandes, A. M. and de Sousa, R. L. (2017): Molecular characterization and genetic diversity of bovine Kobuvirus, Brazil. Virus Genes 53, 105-110.

Cho, Y. I. and Yoon, K. J. (2014): An overview of calf diarrhea - infectious etiology, diagnosis, and intervention. J. Vet. Sci. 15, 1-17.

Di Martino, B., Di Profio, F., Di Felice, E., Ceci, C., Pistilli, M. G. and Marsilio, F. (2012): Molecular detection of bovine kobuviruses in Italy. Arch. Virol. 157, 2393-2396.

Du, J., Lu, L., Liu, F., Su, H., Dong, J., Sun, L., Zhu, Y., Ren, X., Yang, F., Guo, F., Liu, Q., Wu, Z. and Jin, Q. (2016): Distribution and characteristics of rodent picornaviruses in China. Sci. Rep. 6, 34381.

Firth, C., Bhat, M., Firth, M. A., Williams, S. H., Frye, M. J., Simmonds, P., Conte, J. M., Ng, J., Garcia, J., Bhuva, N. P., Lee, B., Che, X., Lan Quan, P. and Lipkin, W. I. (2014): Detection of zoonotic pathogens and characterization of novel viruses carried by commensal Rattus norvegicus in New York City. MBio 5, e01933-14-e01933-14.

Gür, S., Akça, Y. and Burgu, İ. (2006): Serological investigation of bovine enterovirus type-1 in buffaloes in Turkey [in Turkish]. Ankara Üniv. Vet. Fak. Derg. 53, 191-194. 
Gür, S., Yapkiç, O. and Yilmaz, A. (2008): Serological survey of bovine enterovirus type 1 in different mammalian species in Turkey. Zoonoses Public Health 55, 106-111.

Jeoung, H. Y., Lim, J. A., Jeong, W., Oem, J. K. and An, D. J. (2011): Three clusters of bovine kobuvirus isolated in Korea, 2008-2010. Virus Genes 42, 402-406.

Jiménez-Clavero, M. A., Escribano-Romero, E., Mansilla, C., Gomez, N., Cordoba, L., Roblas, N., Ponz, F., Ley, V. and Saiz J. C. (2005): Survey of bovine enterovirus in biological and environmental samples by a highly sensitive real-time reverse transcription-PCR. Appl. Environ. Microbiol. 71, 3536-3543.

Khamrin, P., Maneekarn, N., Peerakome, S., Okitsu, S., Mizuguchi, M. and Ushijima, H. (2008): Bovine kobuviruses from cattle with diarrhea. Emerg. Infect. Dis. 14, 985-986.

Knowles, N. and Mann, J. (1990): Bovine enteroviruses. In: Virus Infections of Vertebrates. Volume 3 - Virus Infections of Ruminants. Elsevier Scientific Publishers Ltd., Amsterdam. pp. 513-516.

Ley, V., Higgins, J. and Fayer, R. (2002): Bovine enteroviruses as indicators of fecal contamination. Appl. Environ. Microbiol. 68, 3455-3461.

Li, Y., Chang, J., Wang, Q. and Yu, L. (2012): Isolation of two Chinese bovine enteroviruses and sequence analysis of their complete genomes. Arch. Virol. 157, 2369-2375.

MacLachlan, J. and Dubovi, J. E. (2017): Picornaviridae. In: Fenner's Veterinary Virology, 5th edition. Elsevier, New York. pp. 477-495.

Melegari, I., Di Profio, F., Sarchese, V., Martella, V., Marsilio, F. and Di Martino, B. (2016): First molecular evidence of kobuviruses in goats in Italy. Arch. Virol. 161, 3245-3248.

Okonechnikov, K., Golosova, O., Fursov, M. and UGENE Team (2012): Unipro UGENE: A unified bioinformatics toolkit. Bioinformatics 28, 1166-1167.

Otomaru, K., Naoi, Y., Haga, K., Omatsu, T., Uto, T., Koizumi, M., Masuda, T., Yamasato, H., Takai, H., Aoki, H., Tsuchiaka, S., Sano, K., Okazaki, S., Katayama, Y., Oba, M., Furuya, T., Shirai, J., Katayama, K., Mizutani, T. and Nagai, M. (2016): Detection of novel kobulike viruses in Japanese black cattle in Japan. J. Vet. Med. Sci. 78, 321-324.

Pankovics, P., Boros, Á., Bíró, H., Horváth, K. B., Phan, T. G., Dewalt, E. and Reuter, G. (2016): Novel picornavirus in domestic rabbits (Oryctolagus cuniculus var. domestica). Infect. Genet. Evol. 37, 117-122.

Park, S. J., Kim, H. K., Song, D. S., Moon, H. J. and Park, B. K. (2011): Molecular detection and genetic characterization of kobuviruses in fecal samples collected from diarrheic cattle in Korea. Infect. Genet. Evol. 11, 1178-1182.

Pham, N. T., Khamrin, P., Nguyen, T. A., Kanti, D. S., Phan, T. G., Okitsu, S. and Ushijima, H. (2007): Isolation and molecular characterization of Aichi viruses from fecal specimens collected in Japan, Bangladesh, Thailand, and Vietnam. J. Clin. Microbiol. 45, 2287-2288.

Reuter, G. and Egyed, L. (2009): Bovine kobuvirus in Europe. Emerg. Infect. Dis. 15, 822-823.

Reuter, G., Boros, Á. and Pankovics, P. (2011): Kobuviruses - a comprehensive review. Rev. Med. Virol. 21, 32-41.

Reuter, G., Boros, Á., Pankovics, P. and Egyed, L. (2010): Kobuvirus in domestic sheep, Hungary. Emerg. Infect. Dis. 16, 869-870.

Reuter, G., Pankovics, P., Knowles, N. J. and Boros, Á. (2012): Two closely related novel picornaviruses in cattle and sheep in Hungary from 2008 to 2009, proposed as members of a new genus in the family Picornaviridae. J. Virol. 86, 13295-13302.

Ribeiro, J., Lorenzetti, E., Alfieri, A. F. and Alfieri, A. A. (2014): Kobuvirus (Aichivirus B) infection in Brazilian cattle herds. Vet. Res. Commun. 38, 177-182.

Smits, S. L., Raj, V. S., Oduber, M. D., Schapendonk, C. M. E., Bodewes, R., Provacia, L., Stittelaar, K. J., Osterhaus, A. D. M. E. and Haagmans, B. L. (2013): Metagenomic analysis of the ferret fecal viral flora. PLoS One 8, 8-e71595.

Yamashita, T., Ito, M., Kabashima, Y., Tsuzuki, H., Fujiura, A. and Sakae, K. (2003): Isolation and characterization of a new species of kobuvirus associated with cattle. J. Gen. Virol. 84, 3069-3077. 
Yamashita, T., Kobayashi, S., Sakae, K., Nakata, S., Chiba, S., Ishihara, Y. and Isomura, S. (1991): Isolation of cytopathic small round viruses with BS-C-1 cells from patients with gastroenteritis. J. Infect. Dis. 164, 954-957.

Yilmaz, H., Turan, N., Altan, E., Bostan, K., Helps, C. R. and Cho, K. O. (2011): First report on the phylogeny of bovine norovirus in Turkey. Arch. Virol. 156, 143-147.

Zell, R. (2018): Picornaviridae - the ever-growing virus family. Arch. Virol. 163, 299-317.

Zell, R., Delwart, E., Gorbalenya, A. E., Hovi, T., King, A. M. Q., Knowles, N. J., Lindberg, A. M., Pallansch, M. A., Palmenberg, A. C., Reuter, G., Simmonds, P., Skern, T., Stanway, G., Yamashita, T. and ICTV Report Consortium (2017): ICTV Virus Taxonomy Profile: Picornaviridae. J. Gen. Virol. 98, 2-3. 